\title{
A Study on Socio-economic Profile of the Broiler Farmers in Mizoram
}

\author{
Lalruatfela Sailo and Samares Kumar Das*
}

Department of Veterinary \& Animal Husbandry Extension, College of Veterinary Science \& Animal Husbandry, Central Agricultural University, Selesih, Aizawl, Mizoram (796 015), India

\section{Corresponding Author}

Samares Kumar Das

e-mail: samcau.d1@gmail.com

\author{
Article History \\ Article ID: AR1876 \\ Received in $21^{\text {st }}$ May, 2018 \\ Received in revised form 29 $9^{\text {th }}$ May, 2018 \\ Accepted in final form $04^{\text {th }}$ June, 2018
}

\begin{abstract}
Transformed from backyard rearing to commercially organized industry in last five decades, India is the second largest egg producer and third largest broiler-chicken producer in the world. Mizo people traditionally rear poultry in the backyard. Poultry production in Mizoram took turn in the late eighties with establishment of broiler farms in the state. Though there is no large scale poultry farm in Mizoram, almost 70 percent of the farmers keep poultry for subsidiary income. Though studies were abundant in other states of India, studies on broiler farming are rare in Mizoram. Keeping this in view, a research was undertaken to study the socio-economic profile of the broiler farmers to help R\&D professionals to improve the situations. Two districts, Aizawl and Kolasib, were selected purposively for the based on the number of broiler farms. From each district, two development blocks and from each block five villages were selected purposively based on the number of broiler farms. Total 20 villages were selected. From each village five farmers engaged in broiler farming were selected randomly. So, the total number of respondents for the study was 100, i.e. 50 from each district. A pre-tested semi-structured interview schedule was used for data collection. The data were compiled, tabulated and analyzed using percentage, frequency and chi-square test. Results revealed that majority of the farmers were middle-aged male with middle school education living in nuclear medium size family rearing a flock of 100-1,000 birds. They always used television and newspaper. A study on extension education service need assessment of the broiler farmers is recommended.
\end{abstract}

Keywords: Socio-economic profile, Broiler farmers, Aizawl, Mizoram

\section{Introduction}

The poultry sector in India has transformed from backyard rearing to commercially organized industry in last five decades. India is the second largest egg producer and third largest broiler-chicken producer in the world (Pratab and Carin, 2015) with 69.73 billion eggs produced at the beginning of the Twelfth Five-Year Plan (Rath et al., 2015). Poultry rearing has been a traditional practice in Mizoram since time unknown. Mizo people rear poultry in the backyard on home grown feed with cheap housing made of locally available materials like woods, bamboo, etc. (Angela, 2014). However, poultry production in Mizoram has taken a new turn in the late eighties with establishment of broiler farms in various parts of the state. Though there is no large scale poultry farm in Mizoram, almost 70 percent of the farmers keep poultry for subsidiary income. The estimated number of broilers available for consumption in the state during 2012-13 was 847,763 and net meat production was 1,561 t. The per capita availability of broiler meat for the year 2012-13 was estimated at $1.39 \mathrm{~kg}$

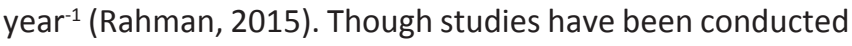

in other states of India, studies on broiler farming are rare in Mizoram. Keeping this in view a study was undertaken to study the socio-economic profile of the broiler farmers which may help R\&D professionals to improve the situations.

\section{Materials and Methods}

Two districts, Aizawl and Kolasib, were selected purposively for the sample survey based on the number of broiler farms. From each district, two development blocks and from each block five villages were selected purposively based on the number of broiler farms. So, a total of 20 villages were selected. From each village five farmers engaged in broiler farming were selected randomly. So, the total number of respondents for the study was 100 , i.e. 50 from each district. For the purpose of data collection a semi-structured interview schedule was prepared covering all the objectives which was pre-tested. Observation was judiciously done to complement and supplement data collected by interview schedule. Secondary data were collected from the published reports, statistical handbooks, economic survey reports, journals and newspapers, etc. The collected data were compiled, tabulated 
and analyzed using percentage, frequency and chi-square test using Statistical Package for the Social Sciences (SPSS).

\section{Results and Discussion}

\subsection{Age}

Table 1 shows that majority of the farmers belonged to middle age group ( $55 \%$ ) followed by old ( $28 \%$ ) and young age group (17\%).

\begin{tabular}{llcc}
\hline \multicolumn{4}{l}{ Table 1: Age of the respondents } \\
\hline Category & Year & $\begin{array}{r}\text { Frequency and } \\
\text { percentage } \\
(\mathrm{N}=100)\end{array}$ & Mean \pm SD \\
\hline Young & Up to 35 & 17 & $48.00 \pm 13.67$ \\
Middle & $36-50$ & 55 & \\
Old & 51 and above & 28 & \\
\hline
\end{tabular}

$\chi^{2}=1.110$ at $2 \mathrm{df}$ (Non-significant)

Etuk et al. (2015) reported that majority (74.5\%) of the broiler farmers were in their productive age (31-50 years). Elizabeth et al. (2011) also reported that the average age of broiler farmers was 42 years in both the districts of Kohima and Dimapur in Nagaland. Borthakur et al. (2010) reported that highest number of respondents (71\%) were 31-48 years old. This might be due to the fact that middle-aged people were productive and broiler farming needed active and productive people. Besides, opportunities for gainful employment in government and private sector were less at this age.

\subsection{Sex}

Table 2 shows that majority of the respondents (64\%) were male involved in broiler farming activity compared to the female counterpart (36\%).

Oni et al. (2005) observed that $86 \%$ of the respondents were male and $14 \%$ were female. Elizabeth et al. (2011) reported that men dominated broiler farming activities in both Kohima (55\%) and Dimapur (56\%) district of Nagaland. The reason might be that broiler farming requires more attention on feeding, watering and marketing for which males were more suitable than females.

\begin{tabular}{lc}
\hline \multicolumn{2}{l}{ Table 2: Sex of the respondents } \\
\hline Category & Frequency and percentage $(\mathrm{N}=100)$ \\
\hline Male & 64 \\
Female & 36 \\
\hline
\end{tabular}

$\chi^{2}=0.174$ at $1 \mathrm{df}$ (Non-significant)

\subsection{Education}

Highest number of respondents had education up to middle school (37\%) followed by primary $(21 \%)$, high (19\%) and higher secondary (13\%) school. Besides, 10\% respondents were graduates, but none was illiterate (Table 3 and Figure 1). Gogoi (2004) observed that most of the farmers (48\%) had education above high school but below graduation and

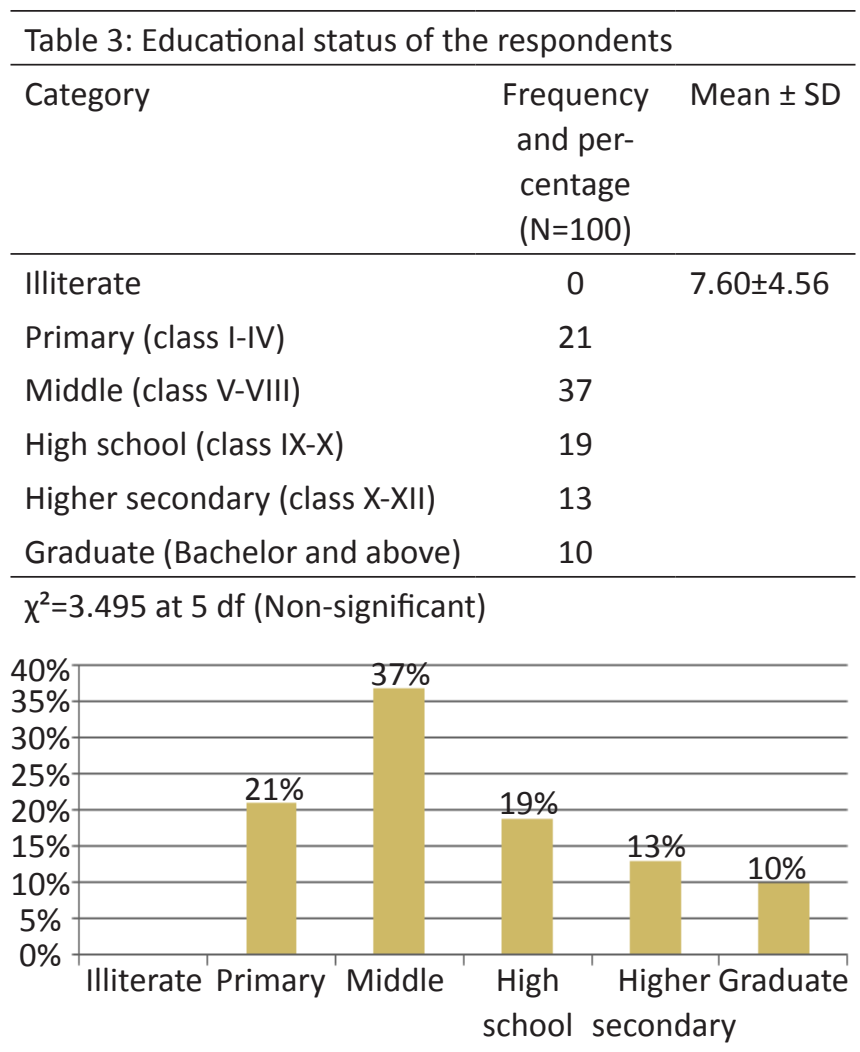

Figure 1: Educational status of the respondents

29 percent had higher education (graduation and above). Borthakur et al. (2010) reported that the educational qualification of majority (48\%) of the respondents was above high school and below graduation. The possible reason might be that persons with higher education had other employment opportunities in government and private sector. Persons with medium and low education were more involved in broiler farming due to fewer opportunities in government and private sector. Further, educated persons had access to information from various sources which enabled them to become a successful farmer than the less or uneducated ones.

\subsection{Family size}

Table 4 shows that majority of the broiler farmers (67\%) belonged to medium size family (6-8 members) followed by small (up to 5 members, 17\%) and large family ( 9 and above members, $16 \%)$.

\begin{tabular}{lcc}
\hline \multicolumn{3}{l}{ Table 4: Family size of the respondents } \\
\hline Family size & $\begin{array}{c}\text { Frequency and } \\
\text { percentage }(\mathrm{N}=100)\end{array}$ & Mean \pm SD \\
\hline Up to 5 (small) & 17 & $5.00 \pm 1.83$ \\
$6-8$ (medium) & 67 & \\
9 and above (large) & 16 & \\
\hline
\end{tabular}

$\chi^{2}=1.614$ at $2 \mathrm{df}$ (Non-significant) 
Similar finding was also reported by Oni et al. (2005) that 39 percent of the respondents had less than 6 members per household in Nigeria. Bora (1999) reported that majority of the respondents (48\%) had medium family (5-6 members) followed by small family (32\%, below 4 members) and large family (20\%, 7 and above members). It might be due to the fact that farming required reasonable number of family members to look after the flock.

\subsection{Family type}

A look into Table 5 reveals that the majority of the broiler farmers (70\%) belonged to nuclear family followed by joint (19\%) and single parent family (11\%).

Similar finding was reported by Borthakur et al. (2010) that majority of the poultry farmers had nuclear family. Borgohain (1993) observed that majority of the poultry farmers belonged to nuclear family (88\%) and 12 percent belonged to joint family. Most of the respondents lived separately after marriage and broiler farming was being carried out by these nuclear families.

Table 5: Family type of the respondents

\begin{tabular}{lc}
\hline Type & Frequency and percentage $(\mathrm{N}=100)$ \\
\hline Nuclear family & 70 \\
Single parent family & 11 \\
Joint family & 19 \\
\hline
\end{tabular}

$\chi^{2}=0.201$ at $2 \mathrm{df}$ (Non-significant)

\subsection{Occupation}

Table 6 reveals that majority of the farmers were agriculturists $(35 \%)$ in occupation followed by broiler farmers $(27 \%)$, government servant (20\%), non-agricultural labourers (11\%) and craftsmen (7\%).

\begin{tabular}{lc}
\hline Table 6: Occupational status of the respondents \\
\hline Occupation & Frequency and percentage (N=100) \\
\hline Agriculture & 35 \\
Broiler farming & 27 \\
Non-agricultural la- & 11 \\
bourer & \\
Craftsmanship & 7 \\
Government service & 20 \\
\hline$\chi^{2}=4.717$ at 4 df (Non-significant) &
\end{tabular}

Mozumdar et al. (2009) reported that $46 \%$ respondents were crop producers, 34\% broiler farmers, $8 \%$ service holders and $12 \%$ businessmen, fishermen and others. However, Gogoi (2004) found that $40 \%$ of the respondents were service holders, $30 \%$ were businessmen and $20 \%$ were farmers. Only $27 \%$ farmers were involved in broiler farming as their main occupation might be due to the lack of knowledge about broiler farming, its benefit and lack of interest. Another reason might be that people preferred piggery over broiler farming.

\subsection{Land holding}

A good number of the farmers (28\%) were small land holders (1-2 ha), followed by marginal (up to 1 ha, 24\%), semi-medium (2-4 ha, 22\%) and medium (4-10 ha, 11\%) land holders. Fifteen percent of the respondents were landless (Table 7).

\begin{tabular}{lcc}
\hline \multicolumn{3}{l}{ Table 7: Land holding of the respondents } \\
\hline Family size & $\begin{array}{c}\text { Frequency and per- } \\
\text { centage ( } \mathrm{N}=100)\end{array}$ & Mean \pm SD \\
\hline Landless (No land) & 15 & $1.75 \pm 1.70$ \\
Marginal (Up to 1 ha) & 24 & \\
Small (1-2 ha) & 28 \\
Semi-medium (2-4 ha) & 22 & \\
Medium (4-10 ha) & 11 & \\
$\chi^{2}=7.916$ at 4 df (Non-significant)
\end{tabular}

According to Elizabeth et al. (2011), average land holding of the broiler farmers in Dimapur (1.75 acres) was more than that in Kohima (1.618 acres). Francis (2016) also found that most of the respondents (74\%) were small land holders followed by marginal (14\%), landless (8\%) and medium (4\%) farmers. The reason why small and marginal land holders were more in the present study might be because being a hilly area there was less opportunity to have large land holding.

\subsection{Income}

Table 8 shows that 7 percent respondents had an annual income below ₹ 63,960 (low income group) followed by 28 percent had annual income ₹ 63,960-83,066 (medium income group) and $65 \%$ had an annual income more than ₹ 83,066 (high income group).

Elizabeth et al. (2011) found that annual income from chicken rearing was ₹ 48,996 and ₹ 78,246, respectively in Kohima and Dimapur district of Nagaland. In the present study most of the respondents belonged to high income group because they had other sources of income besides broiler farming.

\begin{tabular}{lc}
\hline Table 8: Annual income of the family & \\
\hline Category & $\begin{array}{c}\text { Frequency and } \\
\text { percentage ( } \mathrm{N}=100)\end{array}$ \\
\hline Low income (Below ₹ 63,960) & 7 \\
Medium income ( ₹ 63,960-83,066) & 28 \\
High income (Above ₹ 83,066) & 65 \\
\hline
\end{tabular}

$\chi^{2}=62.2523$ at $2 \mathrm{df}$ (Non-significant)

\subsection{Reason for starting broiler farming}

Broiler fetched more price than desi birds was the reason for starting broiler farming by large number (30\%) of the respondents. Faster growth and lower investment cost were 
the reasons for $23 \%$ and $17 \%$ of the respondents, respectively. Easy to be managed by women and stable market were the reason for starting broiler farm for $12 \%$ of the respondents, whereas 6 percent of the respondents started broiler farming because they heard good things from their neighbors (Table 9).

This might be due to the reason that job opportunity in government and non-government sector was less. Hence, people got them employed in broiler farming to complement and supplement their income.

\begin{tabular}{lc}
\hline $\begin{array}{l}\text { Table 9: Reasons for starting boiler farming by the respon- } \\
\text { dents }\end{array}$ & $\begin{array}{c}\text { Frequency and } \\
\text { percentage }(\mathrm{N}=100)\end{array}$ \\
\hline Reasons & 6 \\
\hline Motivated by neighbour & 12 \\
Easy to be managed by women & 17 \\
Lower investment cost & 30 \\
Better price than desi birds & 12 \\
More stable market & 23 \\
Broiler grows faster &
\end{tabular}

$\chi^{2}=20.261$ at $5 \mathrm{df}$ (Non-significant)

\subsection{Flock size}

A look into Table 10 reveals that majority of the respondents (66\%) had medium size (300-1,000 birds) followed by small size (25\%, $100-300$ birds) and large size $(9 \%, 1,000$ and above birds) flock.

Mozumdar et al. (2009) found that small broiler farmers (300-2,000 birds) dominated the rural areas of Mymensingh in Bangladesh. Flock size of 300-1,000 birds was very less in comparison to other states of India. It might be due to difficulty in marketing, high cost of feed, lack of transportation, and unavailability of land and space.

\begin{tabular}{lcc}
\hline \multicolumn{3}{l}{ Table 10: Flock size owned by the respondents } \\
\hline Category & $\begin{array}{r}\text { Frequency and per- } \\
\text { centage }(\mathrm{N}=100)\end{array}$ & Mean \pm SD \\
\hline Small size $(100-300)$ & 25 & $688.45 \pm$ \\
Medium size $(300-1,000)$ & 66 & 374.09 \\
Large size $(1,000$ and & 9 & \\
above) & & \\
\hline$\chi^{2}=42.172$ at 2 df (Non-significant)
\end{tabular}

\subsection{Training}

Table 11 shows that $49 \%$ of the respondents received training from the feed dealer and $7 \%$ received training from the Krishi Vigyan Kendra. None of them received training from veterinary dispensary, veterinary/agricultural university, NGOs and co-operative societies. Thus, only 56 percent of the respondents received training on broiler farming.
Elizabeth et al. (2011) found that respondents trained in Dimapur and Kohima were $18 \%$ and $13 \%$, respectively. Borthakur et al. (2010) found that $87 \%$ of the respondents in Dibrugarh district of Assam had not undergone any formal training on poultry rearing. Overall, fewer respondents were trained which might be due to the negligence on the part of the broiler farmers and absence of cooperative society in the study area.

\begin{tabular}{lc}
\hline \multicolumn{2}{l}{ Table 11: Training received by the respondents } \\
\hline Category & $\begin{array}{c}\text { Frequency and } \\
\text { percentage }(\mathrm{N}=100)\end{array}$ \\
\hline Veterinary dispensary & 0 \\
Poultry feed dealer & 49 \\
Veterinary/agricultural university & 0 \\
NGOs & 0 \\
Cooperative societies & 0 \\
KVK & 7 \\
\hline$\chi^{2}=6.253$ at 5 df (Non-significant) &
\end{tabular}

\subsection{Extension contact}

Table 12 shows that 51\%, 2\% and 73\% respondents "always" used newspaper, radio and television, respectively. However, 48 percent, $64 \%$ and $25 \%$ respondents "sometimes" used newspaper, radio and television, respectively. The respondents "rarely" used government extension worker/ field worker, NGO extension worker/field worker, newspaper, radio, television and farm publication were $54 \%, 16 \%, 1 \%$, $34 \%, 2 \%$ and $52 \%$, respectively. The respondents "never" used government extension worker/field worker, NGO extension worker/field worker and farm publication were 46\%, 84\%, and $48 \%$, respectively.

Fawole (2006) observed that poultry farmers in Nigeria used television (68\%), veterinary personnel (52\%), handbill $(47 \%)$, radio (43\%), farm magazine (32\%), non-governmental

\begin{tabular}{lcccc}
\hline Table 12: Extension services used by the respondents \\
\hline Extension services & \multicolumn{1}{c}{ Frequency and percentage (N=100) } \\
\cline { 2 - 5 } & $\begin{array}{l}\text { Always } \\
\text { Some- } \\
\text { times }\end{array}$ & Rarely & Never \\
\hline $\begin{array}{l}\text { Government exten- } \\
\text { sion worker/field }\end{array}$ & 0 & 0 & 54 & 46 \\
worker & 0 & 0 & 16 & 84 \\
NGO extension & & & & \\
worker/field worker & 51 & 48 & 1 & 0 \\
News paper & 2 & 64 & 34 & 0 \\
Radio & 73 & 25 & 2 & 0 \\
Television & 0 & 0 & 52 & 48 \\
Farm publication & & & & \\
\hline
\end{tabular}


organization (32\%) and extension agent (26\%) as their sources of information. In the present study, television and newspaper were used regularly because the respondents owned television and subscribed newspaper.

\subsection{Farming experience}

Nearly half of the respondents (48\%) had long experience in broiler farming (more than 6 years) followed by $43 \%$ medium experience (2-6 years) and $5 \%$ had short faming experience of less than 1 year (Table 13).

Elizabeth et al. (2011) found that majority of the respondents ( $79 \%$ in Kohima and $87 \%$ in Dimapur) were engaged in poultry farming for 1-7 years. Over all experience in broiler farming was less which might be due to the fact that there was a tendency among respondents to change enterprise for want of better and stable income.

\begin{tabular}{lcc}
\hline \multicolumn{3}{l}{ Table 13: Farming experience of the respondents } \\
\hline Experience (year) & $\begin{array}{c}\text { Frequency and per- } \\
\text { centage }(\mathrm{N}=100)\end{array}$ & Mean $\pm S D$ \\
Short (Below 1 ) & 5 & $3.47 \pm 2.9$ \\
Medium (2-6) & 43 & \\
Long (Above 6) & 48 & \\
\hline
\end{tabular}

$\chi^{2}=5.927$ at $2 \mathrm{df}$ (Non-significant)

\subsection{Financial assistance received}

Only $36 \%$ of the respondents received financial assistance borrowing loan from bank, relative/friend or other sources (Table 14).

Adebayo and Adeola (2005) reported that 68 percent of the respondents were financed through personal savings and friends/relatives, whereas 32 percent were financed through the financial institutions. In the present study, few respondents took financial help mainly from Mizoram Rural Bank due to the fact that they were small farmers and did not require much financial help.

\begin{tabular}{lc}
\hline \multicolumn{2}{l}{ Table 14: Financial help taken by the respondent } \\
\hline Category & $\begin{array}{c}\text { Frequency and per- } \\
\text { centage }(\mathrm{N}=100)\end{array}$ \\
\hline Received & 36 \\
Not received & 64 \\
\hline
\end{tabular}

\subsection{Asset possession}

All the respondents possessed electricity, watch and mobile phone (Table 15). Besides, they possessed fan ( $82 \%)$, colour television (80\%), motorcycle/scooter/moped/scooty (46\%), radio $(39 \%)$, car $(23 \%)$, landline telephone $(21 \%)$, sewing machine $(20 \%)$, bicycle $(14 \%)$ and black and white television (3\%).

Mozumdar et al. (2009) reported that possession of television, sewing machine, dining table, electric fans and mobile

\begin{tabular}{lc}
\hline Table 15: Assets possessed by the respondents \\
\hline Assets & $\begin{array}{c}\text { Frequency and } \\
\text { percentage }(\mathrm{N}=100)\end{array}$ \\
\hline Electricity & 100 \\
Radio & 39 \\
Bicycle & 14 \\
Motorcycle/scooter/moped/ & 46 \\
scooty & \\
Car & 23 \\
Fan & 82 \\
Watch & 100 \\
Black and white television & 3 \\
Colour Television & 80 \\
Landline telephone & 21 \\
Mobile phone & 100 \\
Sewing machine & 20 \\
\hline
\end{tabular}

$\chi^{2}=20.633$ at $11 \mathrm{df}$ (Non-significant)

phone were increased by $170 \%, 88 \%, 109 \%, 84 \%$ and $79 \%$, respectively after adopting broiler farming.

\section{Conclusion}

Majority of the farmers were middle-aged male with middle school education living in nuclear medium size family with the house electrified. Being agricultural labourers with small land holding and high annual income they were rearing 300-1,000 birds. With six years of experience in broiler farming they received training mainly from the feed dealer and watched television and read newspaper. Possessing mobile phone, fan and television they also obtained financial assistance. There is a need to assess extension education service need of the broiler farmers.

\section{References}

Adebayo, O.O., Adeola, R.G., 2005. Socio- economic factors affecting poultry farmers in Ejigbo local government area of Osun state. Journal of Human Ecology 18(1), 39-41.

Angela, L.R., 2014. Effect of age and rearing system on the performance of broiler in Mizoram. MVSc Thesis, Central Agricultural University, Imphal, India.

Bora, L., 1999. Role of farm woman and their training needs in relation to animal husbandry practices in Teju Development Block of Luit district of Arunachal Pradesh. MVSc Thesis, Assam Agricultural University, Guwahati, India.

Borgohain, D., 1993. Working pattern of rural farm woman in relation to livestock rearing in Sapekhati Development Block, Assam. MVSc Thesis, Assam Agricultural University, Guwahati, India.

Borthakur, B., Hazarika, P., Saharia, K.K., 2010. Socioeconomic 
and psychological status of poultry farmers in Dibrugarh district of Assam. Indian Journal of Field Veterinarian 5(4), 67-69.

Elizabeth, Y., Saptoca, D., Saharia, K.K., 2011. Poultry farmers of Kohima and Dimapur districts of Nagaland: A profile. Tamil Nadu Journal of Veterinary \& Animal Sciences 7(3), 210-212.

Etuk, E.A., Nkang, M.O., Henshaw, E.P., 2015. Determinants of poverty status among broiler farmers in Calabar metropolis, Cross River State, Nigeria. Journal of Agriculture \& Veterinary Science 8(3), 9-14.

Fawole, O.P., 2006. Poultry farmers' utilization of information in Lagelu Local Government Area in Oyo State of Nigeria. International Journal of Poultry Science 5(5), 499-501.

Francis, L.S., 2016. Backyard poultry farming in Mizoram: An exploratory study. MVSc Thesis, Central Agricultural University, Imphal, India.

Gogoi, D., 2004. Motivational preferences of rural educated unemployed youths towards animal husbandry in West Siang district of Arunachal Pradesh. MVSc Thesis, Assam Agricultural University, Guwahati, India.
Mozumdar, L., Farid, K.S., Ahmed, J.U., Rahman, M.W., 2009. Broiler farming: An approach to improve rural livelihood. Journal of Bangladesh Agriculture University 7(2), 395-402.

Oni, O.A., Oladele, O.I., Oyewole, I.K., 2005. Analysis of factors influencing loan default among farmers in Ogun state, Nigeria. Central European Agriculture 6(4), 619-624.

Pratab, R., Carin, R., 2015. Current opportunity in India's poultry sector. A Broader Consultancy India Pvt. Ltd., Goa.

Rahman, S., 2015. Management of broiler farms in Aizawl district of Mizoram, India. Livestock Research for Rural Development 27(4). http://www.Irrd.org/Irrd27/4/ cont2704.htm. Accessed on 26 October 2016.

Rath, P.K., Mandal, K.D., Panda, P., 2015. Backyard poultry farming in India: a call for skill upliftment. Research Journal of Recent Sciences 4, 1-5. 